\title{
論文特集「表面・界面の機能化」
}

(日本化学会誌, 1985, (6), p. 1178 1186)

(C) 1985 The Chemical Society of Japan

\section{メロシアニン色素光ダイオードの 光電流過渡応答と発光寿命}

\author{
(1984 年 11 月 21 日 受 理)
}

橋本和仁・坂田忠良*・尾崎幸洋**・吉浦昌彦**・入山啓治**

\begin{abstract}
メロシアニン系色素蒸着膜をアルミニウムと銀薄膜で挟んだ形をもつ光ダイオードの光電流発生機構 を，色素膜からの蛍光の寿命測定と，励起光源としてパルスレーザーを用いた過渡光電流の測定により 調べた。発光寿命の測定から色素膜の一重項励起子の寿命は約 200 ps であることがかかった。過渡光 電流応答の解析により, 光電流の立ち上がりは励起子の拡散過程により決定されること, さらに励起光 のパルス幅よりも十分遅い応答を示すことから，電荷キャリャー生成の前駆体である励起子の寿命は数 $100 \mathrm{~ns}$ あることが推定された。以上の結果から, 電荷キャりャーは三重項励起子のような長寿命中間体 が色素膜内を払散し，バルク中のトラップとの相互作用による解離，さらに金属との界面での解離によ り生じていると推定できた。また，過渡光電流の減衰は回路の時定数により決まり，それからセルの内 部容量, 内部抵抗が得られ, さらに色素膜内での電荷キャリャーの再結合の速度定数が求められた。そ のほか, パルス光照射に特有の興味ある現象がいくつかみられた。
\end{abstract}

\section{1 楮 言}

有機材料のらち，半導体性を示すむのを用いた光電変換素子 は，軽量，低コスト，量産性に優れているだけでなく，生体内に 拈ける光合成，視覚反応の初期過程との関連も含めて注目されて

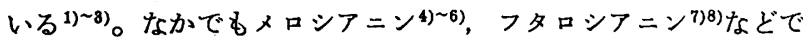
構成された有機色素薄膜光ダイオードは, 他の有機材料にくら へ，かなり大きな光電変換効率を示し, また, 通常の蒸着法や, 簡単な塗布方法でも薄膜を得ることができるため, 多くの研究が 報告されている。たとえば，米国のェクソン社のグループは，ア

分子科学研究所, 444 岡崎市明大寺町西郷中

** 東京慈恵会医科大学共同利用研究部分析 機器室, 105 東 京都港区西新橋

1）田伏岩夫, 松尾 拓, “化学增刊 82 明日のエネルギーと化 学”, 化学同人 (1979) p. 98.

2) 入山啓治, 固体物理, 16, 96(1981).

3）工藤一浩, 塩川祥子, 森泉豊栄, 入山啓治, 杉 道夫, 電 気化学協会論文誌, 101-A，347(1981).

4) D. L. Morel, A. K. Ghosh, T. Feng, E. L. Stogryn, P. E. Purwin, C. Fishman, Appl. Phys. Lett., 32, 495 (1978)

5) A. K. Ghosh, T. Feng, J. Appl. Phys., 49, 5982 (1978).

6) K. Iriyama, M. Shiraki, T. Tsuda, A. Okada, M. Sugi, S. Iijima, K. Kudo, S. Shiokawa, T. Moriizumi, T. Yasuda, Jpn. J. Appl. Phys. Supple., 19-2, 173 (1979).

7) A. K. Ghosh, D. L. Morel, T. Feng, R. F. Shaw, C. A. Rowe, Jr., J. Appl. Phys., 45, 230(1974).

8) R. O. Loufty, J. H. Sharp, J. Chem. Phys., 71, 1211 (1979).
ルミニウム半透明電極（透過率約 $50 \%$ ）を支持電極として，そ の上にメロシアニン蒸着膜，ついで銀電極でオーミック接触をと ったサンドイッチ形セルを满築し，AM1 評価で実測值 $0.7 \%$ の 変換効率を得ている(4)5)。た，開放電正 $\left(V_{\text {oc }}\right)$ が $1.5 \mathrm{~V}$ に近い ものが得られている。色素の分子構造や，分子集合体を変化させ ることによって比較的自由に吸収スペクトルを変化させることが できる利点もある。色素の安定珄に問題が残っているが，光電素 子としての発展が期待されている。今後さらに効率のよい有機溥 膜太陽電池の開発のためにも，このような色素薄膜光ダイオード の光電流, 光起電力発生の機構 (とくに電荷キャリャ一生成過 程), アモルファス色素薄膜の特性を明らかにすることが重要で あるが，その研究例は少ない。

一方, 著者らは半導体電極湿式電池 ${ }^{92}$ 13), 色素増感半導体電極 湿式電池 ${ }^{14)}$ にパルス光を照射したときの過派光電流を测定し，半 導体内部での電荷分離, 溶液-半導体界面での電荷移動, 励起色 素から半導体への電子移動，電極の内部抵抗などに関する情報 を, 光電流応答曲線の解析から得る試みをしている。さらに吸着

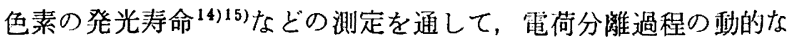
情報も得ている。

9) T. Kawai, H. Tributsch, T. Sakata, Chem. Phys. Lett., 69, 336(1980).

10）坂田忠良，川合知二，電子デバィス・新省エネルギー合同 研究会資料, p. $27 \sim 35(1980)$.

11) T. Sakata, E. Janata, W. Jaegerman, H. Tributsch, J. Electrochem., in press.

12) R. H. Wilson, T. Sakata, T. Kawai, K. Hashimoto, ibid., in press.

13）坂田忠良，桐本和仁，未発表.

14）橾本和仁，坂田忠良，未発表。 
<smiles>Cn1c(=O)sc2ccccc21</smiles>

$\left(\mathrm{CH}_{2}\right)_{\mathrm{mH}}$<smiles>CC=C1SC(=S)N(C)C1=O</smiles>

$\left(\mathrm{CH}_{2}\right)_{n} \mathrm{COOH}$

Merocyanine Dye $(m, n)$

Fig. 1 Molecular structure of merocyanine dyes

そこで本報文では，典型的な有機太陽電池である，Al/メロシ アニン系色素/Ag 光ダイオードにレーザーパルス光を照射する ことにより得られる過渡光電流応答の测定と，色素薄膜からの蛍 光娍衰の測定を常なった。その結果, 光電流応答を決める因子, 電荷キャリヤー生成機構, などについていくつかの知見が得られ たので報告する。

\section{2 実験}

\section{1 色素薄膜, および薄膜光ダイオードの作製}

実験に用いた色素は図 1 に括いて $(m, n)=(1,2),(2,1)$ ， $(13,1)$ の 3 種である。これらは日本感光色素研究所から市眅さ れているものを用いた。金属／色素／金属構造のダイオードは, 真空蒸着法（背压 $5 \times 10^{-4} \sim 1 \times 10^{-3} \mathrm{~Pa}$ ）により作製した ${ }^{3)}$ 。がラ ス基板上に $\mathrm{Al}$ を半透明膜となるように蒸着し（約 $150 \AA ̊$ ），暗 所, デシヶーター中に一昼夜放置後, 色素膜を $200 \sim 2000 \AA$ 蒸 着し，最後に $\mathrm{Ag}$ を約 $300 \AA$ 蒸着した。有効電極面積は約 $1 \mathrm{~cm}^{2}$ である。このようにして得られた光ダイオードの特性は, 約 2 $\mathrm{mW}$ の単色光照射で, 短絡光電流 $\left(I_{\mathrm{sc}}\right) 1 \sim 10 \mu \mathrm{A}, V_{\mathrm{oc}}$ は, $0.8 \sim 1.0 \mathrm{~V}$ であり, 金属膜での入射光の吸収と反射を考虑に入 れるとほぼ以前の報告3)4)6) と一致する。

\section{2 蛍光減衰の測定}

パルス光源として，シンクロナス励起モード同期色素レーザー (Spectra Physics 171-18) を用いた ${ }^{16)}$ 。色素レーザーはくり返 し速度 $800 \mathrm{kHz}$ で発振させ, 1 個のパルスの時間は $6 \mathrm{ps}$ (半值 幅), パルスあたりの出カエネルギーは約 $1 \mathrm{~nJ} \cdot \mathrm{cm}^{-2}(550 \mathrm{~nm})$ で ある。観測は単一光子計数法によって行なった。光電子増倍管と してマイクロチャネルプレート方式のものを用いているため, 電 子走行時間の広がりが小さく、レーザーの散乱パルスは約 70 ps の半值幅をもって観測される。なお, 本測定装置は分子科学研究 所, 機器センター所有のるのである。

\section{3 光電流過渡応答の測定}

パルス光源として, 窒素レーザー（Molectron UV 22）励起 の色素レーザー（Molectron DL 14）を用いた。色素は扰もに エキシトン社のクマリン 520 を用い，とくに断らないかぎり 540 $\mathrm{nm}$ の光を励起光とした。パルス幅は約 $6 \mathrm{~ns}$ (半值幅)である。

図 2 に示すように, 光照射により発生した光電流は外部抵抗 $\left(R_{\ominus}\right)$ を通して放電され，そのときに $R_{\theta}$ の雨端に発生する電圧 をオシロスコープ (Tektronix 7104, $1 \mathrm{GHz}$ ) で観測し，そのブ ラウン管上の信号をポラロイドカメラで単発現象としてとらえる か，またはディジタルストレージオシロスコープ（岩崎通信株式

15) T. Kajiwara, K. Hashimoto, T. Kawai, T. Sakata, J. Phys. Chem., 86, 4516(1982).

16）村尾俊郎, 山崎 吱, 進藤善婎, 吉原經太郎, 分光研究, 31, 96(1982).

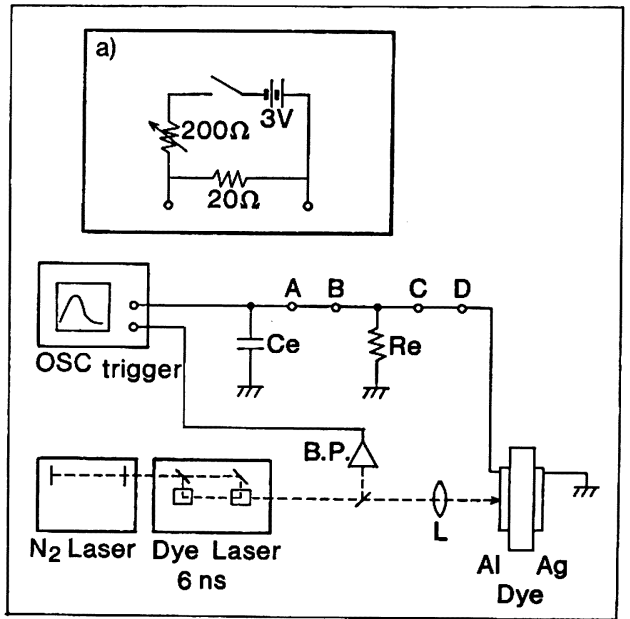

Fig. 2 Experimental arrangement for studies of the transient photocurrent

L : Lens, B. P.: Biplanar phototube, O. S. C.: Oscilloscope.

a) Circuit for the application of external voltage.

会社 TS-8123，100 MHz) を通し，マイクロコンピューター（日 本電気株式会社，9801）で積算した。必要に応して図2の A-B 間に高速增幅器 (Parr 115, $100 \mathrm{MHz}$ ) を挿入し, 信号を増幅し た。C・は接続ケーブルの浮遊容量とオシロスコープ，または増 幅器の入力容量の和である。 $R_{\mathrm{\theta}}$ が光ダイオードの内部抵抗 $\left(R_{1}\right)$ にくらべ十分小さいとさは， $R_{\theta}$ の両端に発生する電圧の時間変 化は， $I_{\mathrm{sc}}$ の時間変化と近似的に一致する。また，必要に応し回 路に直列に抵抗 $\left(R_{\mathrm{a}}\right)$ を C-D 間に挿入した。さらに外部電位依 存性は，図 2-a）に示した乾電池を用いた回路を C-D 間に挿入 することにより， $\mathrm{Al}$ 側の電位を $\mathrm{Ag}$ 側に対し制御した。測定は すべて空気中で行なったが低温での実験の場合のみ, Oxford ク ライオスタット中（約 $10^{-1} \mathrm{~Pa}$ ) に試料を入れた。

\section{3 結果}

\section{1 蛍光寿命}

色素として MD $(2,1)$ を用いた。この色素のメタノール溶液 $\left(10^{-6} \mathrm{~mol} \cdot \mathrm{cm}^{-8}\right)$ での蛍光は, 単一指数関数で減哀し，その寿 命は約 $80 \mathrm{ps}$ と非常に短い。メロシアニン, シアニン系の色素は 一般に分子内回転のために無輻射遷移の速度が増加し, 寿命が短 くなっていると考えられる。実際，この色素の場合も粘度の大き な溶媒中では寿命が長くなった。。たとえばメタノールーグリセリ ン混合溶媒（体積比 $1: 19 ）$ 中では, 発光強度はいちじるしく増 大し, かつ約 $400 \mathrm{ps}$ の寿命となる。その他寿命の短い原因とし て, 色素分子内に硫黄原子を含むため, 内部重原子効果による項 間交差の速度の増大が予想される。

一方，色素蒸着獏では発光強度はいちじるしく減少し，かつ減 衰明線は単一指数関数減衰から大きくはずれ，ほぼ二つの指数関 数の和で近似できるようになる。この蛍光減衰曲線を図 3-(A) に示す。それぞれの成分の寿命は約 $200 \mathrm{ps}$ と $1.8 \mathrm{~ns}$ である。こ のような膜に，強度の大きな光を照射すると，励起子一励起子の 相互作用により発光寿命が減少する場合があるが，本研究で用い た励起パルス光のエネルギーは, $1 \mathrm{~nJ} \cdot \mathrm{cm}^{-2}$ 程度と比較的小さい 

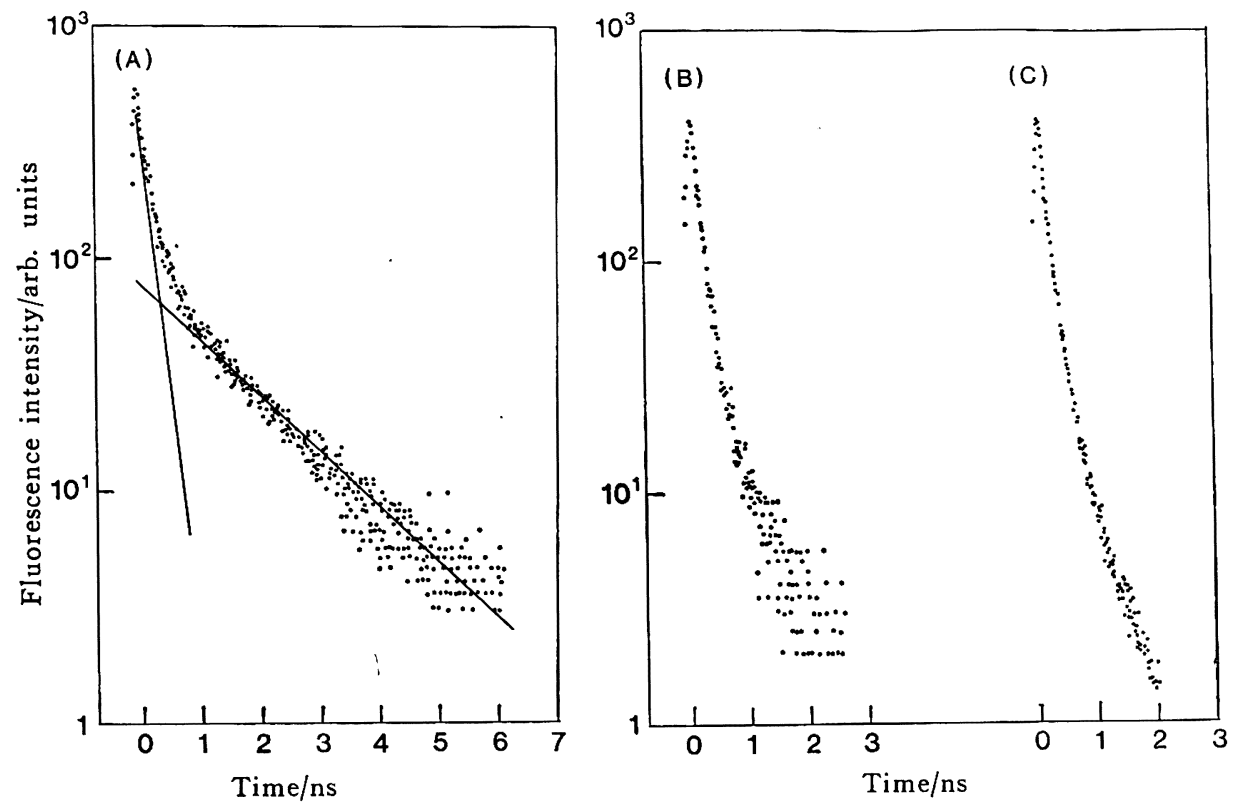

Fig. 3 Fluorescence decay curves of merocyanine dye thin films

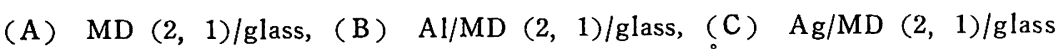
Thickness of dye film : $500 \AA$

ため, レーザー光強度を変化させても蛍光隇衰曲線は変化しなか った。すなわち定常光照射時の稳和な条件での一重項励起子の寿 命に相当すると考えられる。しかし, 発光の量子効率は $10^{-4}$ 以 下であり，無輻射過程の効率が非常に大きい。膜状の場合，粘度 の大きな溶媒中の場合と同様に分子内回転による無輻射失活は減 少するはずであるから，この原因はつぎの二点がおもに考えられ る。

（1）膜中に多数の不純物, あるいはトラップが存在し, それら との相互作用により励起子が失活する。（2）色素分子が, 他の多 くの色素によって曲まれているために，硫黄原子による外部原子 効果が起き項間交差の速度が増大する。このほか, ダイマーの形 成なども蛍光寿命の短い原因として考えられる。

一方, 色素膜の上にさらに $\mathrm{Al}$, または $\mathrm{Ag}$ 膜を蒸着すると遅 い成分はほとんど消光されてしまい，200 ps の寿命をもつ速い 成分だけとなる。このようすは $\mathrm{Al} / \mathrm{MD} / \mathrm{Ag}$ 型のサンドイッチセ ルでも同様であり，遅い成分は金属へのエネルギー移動により消 光していると考えられる ${ }^{17}$ 。

この金属により消光される荤い成分は, 膜中での存在状態が速 い成分と異なるためなのか，それとる蒸着時に生成した不純物に よるすのなのかは現段階では明らかでないが，いずれにしても， サンドイッチ型薄膜光ダイオードの状態での一重項励起子の寿命 は約 $200 \mathrm{ps}$ と結論できる。速い成分の寿命が金属膜の存在によ り寿命が変化しないのは與味深い事実である。このことは，金属 とこの色素膜のェネルギー移動の速さは $200 \mathrm{ps}$ よりもかなり遅 いことを意味している。

\section{2 光電流の過渡応答}

図 2 に示した方法により $\mathrm{Al} /$ メロシアニン色素/ $\mathrm{Ag}$ 型サンド イッチ光ダイオードに数 $\mu \mathrm{J}$ 数 $10 \mathrm{~nJ}$ のパルス光を照射する

17) K. Tanimura, T. Kawai, T. Sakata, J. Phys. Chem., $84,751(1980)$.

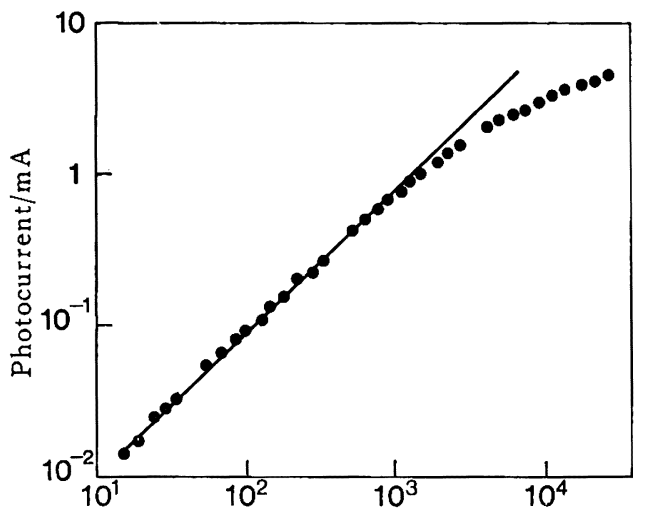

(Light intensity/pulse) $/\left(\mathrm{nJ} \cdot \mathrm{cm}^{-2}\right.$ )

Fig. 4 Dependence of the intensity of transient photocurrent on light intensity

Al/MD (13, 1)/Ag, Dye film thickness : $250 \AA$, Excitation light wavelength : $520 \mathrm{~nm}, R_{\mathrm{e}}: 50 \mathrm{ohm}$

と, オシロスコープ上にナノ秒領域の立ち上がりと, マイクロ秒 領域の減衰をるつ曲線が钼湘される。これは前に記したように $R_{\theta}$ の両端に発生した䉓压， $E(t)$ ，であり， $R_{\mathrm{\theta}}$ が十分小さいと きは近似的に短絡条件に相当し， $j(\mathrm{t})=E(\mathrm{t}) / R_{\theta}$ の関係により $I_{\mathrm{sc}}$ の時間变化, $j(\mathrm{t})$, を表わす。色素を蒸着していない $\mathrm{Al} / \mathrm{Ag}$ 膜に同様に光照射しても, また, 色素の光四収のない波長の光を 照射しても光応答は钼測されないことから色素の励起状態が関与 した光電流であることがわかる。励起光強度を変化させると, 光 電流の時間応答特性は変わらず，強度のみが影響をらける。光電 王応答のピーク值を光電流に換算した值を光強度に対し, 対数一 対数プロットした結果を図 4 に示す。光強度の小さな領城では定 常光照射の埸合と同様に ${ }^{3)}$ 光強度に対し一次で光电流は增加す 


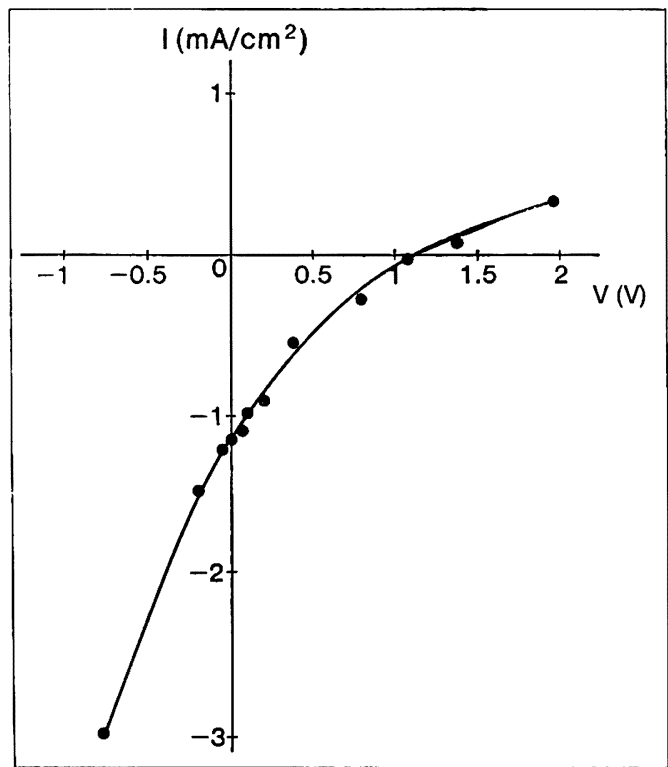

Fig. 5 Transient photocurrent-potential characteristics for $\mathrm{Al} / \mathrm{MD}(13,1) / \mathrm{Ag}$ cell

Dye film thickness: $250 \AA$, Excitation light wavelength : $520 \mathrm{~nm}, R_{\theta}: 50 \mathrm{ohm}$

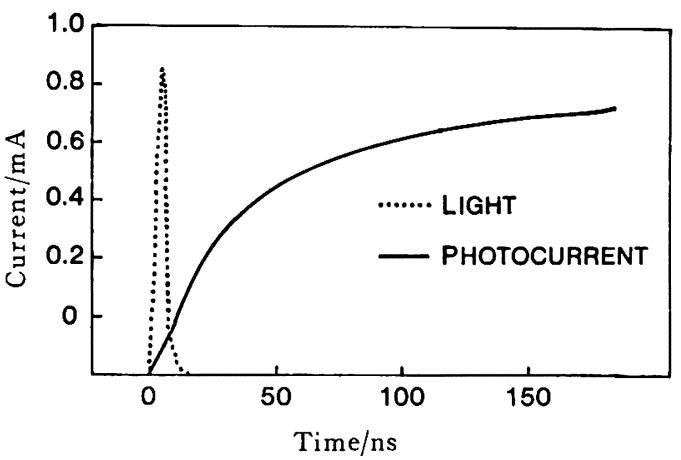

Fig. 6 Time profile of excitation pulse and response of the transient photocurrent in $\operatorname{Al} / \mathrm{MD}(2,1) /$ Ag photodiode

Dye film thickness : $250 \AA, R_{\theta}: 8$ ohm

る。光強度が約 $1 \mu \mathrm{J} \cdot \mathrm{cm}^{-2}$ ・ハルスを越えると電流強度は飽 和し てくるが, 時間応答曲線は光強度が弱い領域でのものと一致する。 パス幅 $6 \mathrm{~ns}$ で $1 \mu \mathrm{J} \cdot \mathrm{cm}^{-2}$ の光パスは尖頭值で約 $170 \mathrm{~W}$. $\mathrm{cm}^{-2}$ の光強度に相当与る。定常光照射のように光励起が連続し て行なわれるときは光強度が $10 \mathrm{~mW} \cdot \mathrm{cm}^{-2}$ を超えると光電流は 飽和するが，ナノ秒のパルス光照射の場合はそのしきい值が 3 ケ 夕程度上昇している。すでに述べた発光寿命の测定ではパルス幅 $6 \mathrm{ps} て ゙ 1 \mathrm{~nJ} \cdot \mathrm{cm}^{-2}$ ・ハルスの励起光を用いたがこれは尖頭値で約 $170 \mathrm{~W} \cdot \mathrm{cm}^{-2}$ でありほぼ光電流が一次で増加する領域に相当する ことがわかる。また，図 2 (a ) に示す回路により外部電位をかけ たときの電位一過渡光電流特性を調べた結果を図 5 に示す。この 特性は定常光照射で得られるものと基本的に同じであり,さらに 電流がゼロとなる電圧 ( $V_{\mathrm{oc}}$ に対応する) も $1.1 \mathrm{~V}$ と定常光照射 時に得られる $V_{\text {oc }}$ とほぼ一致する。
Table 1 Dependence of rise time of transient photocurrent on external resistance $\left(R_{\mathrm{e}}\right)$

\begin{tabular}{|c|c|c|c|}
\hline \multicolumn{2}{|c|}{ Resistance $\left(R_{\mathrm{e}}\right)$} & Rise $(\mathrm{I})^{a(b)}$ & Rise $(I I)^{a)}$ \\
\hline \multicolumn{2}{|c|}{$8.6 \Omega$} & $105 \pm 20 \mathrm{~ns}$ & -c) \\
\hline 25 & $\Omega$ & $105 \pm 20 \mathrm{~ns}$ & $\longrightarrow^{c)}$ \\
\hline 50 & $\Omega$ & $110 \pm 40 \mathrm{~ns}$ & $330 \pm 55 \mathrm{~ns}$ \\
\hline 197 & $\Omega$ & $110 \pm 40 \mathrm{~ns}$ & $1000 \pm 100 \mathrm{~ns}$ \\
\hline 463 & $\Omega$ & $110 \pm 80 \mathrm{~ns}$ & $2200 \pm 200 \mathrm{~ns}$ \\
\hline 1170 & $\Omega$ & $110 \pm 80 \mathrm{~ns}$ & $3300 \pm 400 \mathrm{~ns}$ \\
\hline 1459 & $\Omega$ & $110 \pm 80 \mathrm{~ns}$ & $5100 \pm 600 \mathrm{~ns}$ \\
\hline
\end{tabular}

Al/MD (13, 1)/Ag, Dye film thickness : $1500 \AA$

a) Values of $\tau$ under the assumption that rise curves of transient photocurrent were approximately fitted with double exponential functions as follows, $j(\mathrm{t}) \propto 1-\left[\exp \left(-t / \tau_{1}\right)+\exp \left(-t / \tau_{2}\right)\right]$.

$b)$ These values are strongly dependent on the conditions of evaporation of the dye (see the text).

c) No slow component was observed.

以上の事実から本実験方法により得られる光電流過渡応答は定 常光照射により得られる光電流と同様の機構により生じているも のと結論できる。そこで以下にこれらの過渡応答特性の立ち上が りと減衰を詳しく調べた結果について記す。なお，前に述べた 3 種のメロシアニン型色素を用いてサンドイッチセルを組みたてた が，それらの光電流過渡応答特性に顕著な差は認められなかっ た。

3.2 .1 過渡光電流の立ち上がり特性 : メロシアニン色素薄膜 セルでの光電流過渡応答の立ち上がりは図 6 に示すように励起光 にくらべ非常にゆっくりと上昇する。この立ち上がりのようすは 光ダイオードの温度を室温から液体窒素温度まで変化させてもほ とんど影響をうけなかった。立ち上がりに要する時間は酸化チタ ン, 酸化亚鉛, 酸化インジウムなどを光照射側電極として用いた 半導体湿式電池の場合の $1 \sim 10 \mathrm{~ns}^{9)}$ 〜13), ローズペンガル, ロー ダミン Bなどの有機色素を増感剤とした半導体色素増感湿式電池 の場合 ${ }^{14)}$ の約 $2 \mathrm{~ns}$ などの応答時間にくらべいちじるしく遅い。 また，Ghosh らは $\mathrm{Mg}$ フタロシアニン薄膜を $\mathrm{Al}$ と Ag で㣣 んだ光ダイオードの光電流過渡応答を測定し報告している7)。彼 らの結果によると，光電流はレーザーパルスに追随して $1 \mathrm{~ns}$ 程 度の時間領域で立ち上がっておりり), 本研究でのメロシアニン膜 での結果とまったく異なる。

本研究で得られた立ち上がり曲線は， $R_{\theta}$ を変化させたときの 挙動から， $R_{\mathrm{e}}$ に依存しない比較的速い成分 (I)と, $R_{\mathrm{\theta}}$ に依存する 遅い成分の二成分からなっていることがわかった。それぞれの成 分を指数関数で近似したときの立ち上がり時間を表 1 に示す ${ }^{18)}$ 。 (I)の速度はさらに光ダイオードに直列に抵抗 $\left(R_{\mathrm{a}}=25.0 \Omega\right.$, $83.8 \Omega, 200 \Omega$ )を図 2 の C-D 間に入れても変化せず，また色 素膜厚が異なっても系統的な変化は認められなかった。後述する ように色素膜厚が異なるとセルの内部容量が異なることから（I） の速度は内部容量にも依存しないと結論できる。

このように（Ｉ）は同条件で色素膜を蒸着したセルを用いる範囲 内では種々のパラメータの変化により影䭓をらけないが, 蒸着条 件（蒸着速度, 真空度, 蒸着温度など）にはいちじるしく影響を

18）速い成分は指数関数的立ち上がりからはずれるが，ここで はその速度を知るために便宜上指数関数で近似した。 

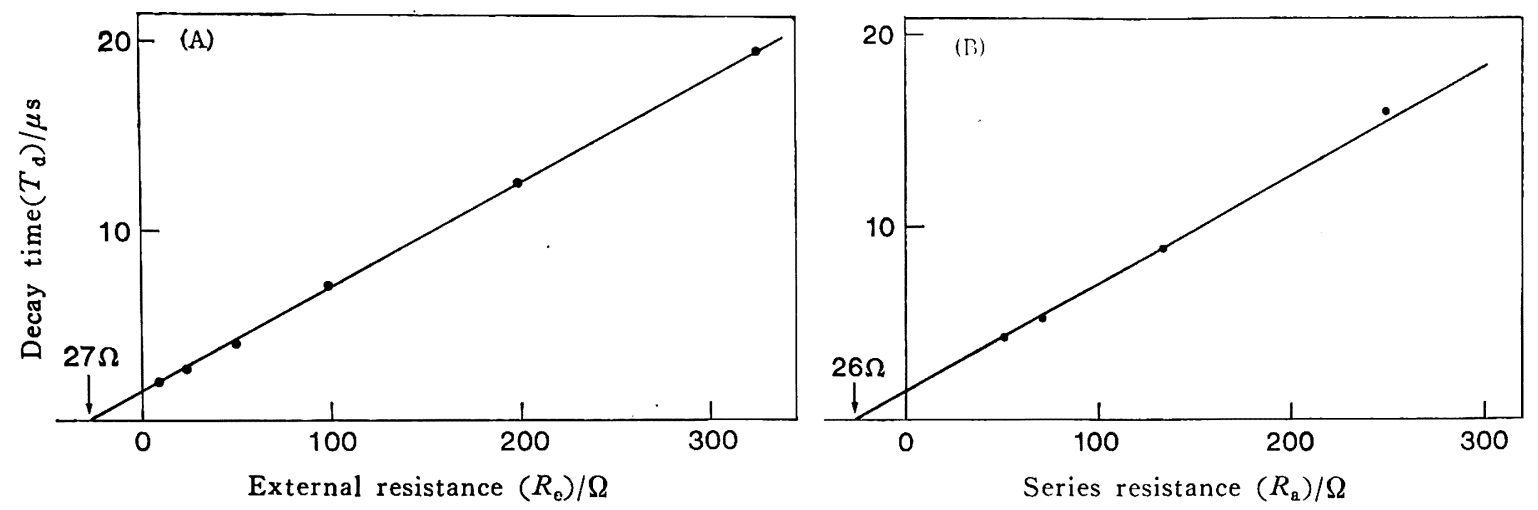

Fig. 7 Dependence of decay time on resistance (see the text)

(A) External resistance $\left(R_{\ominus}\right)$, (B) Series resistance $\left(R_{\mathrm{a}}\right)$
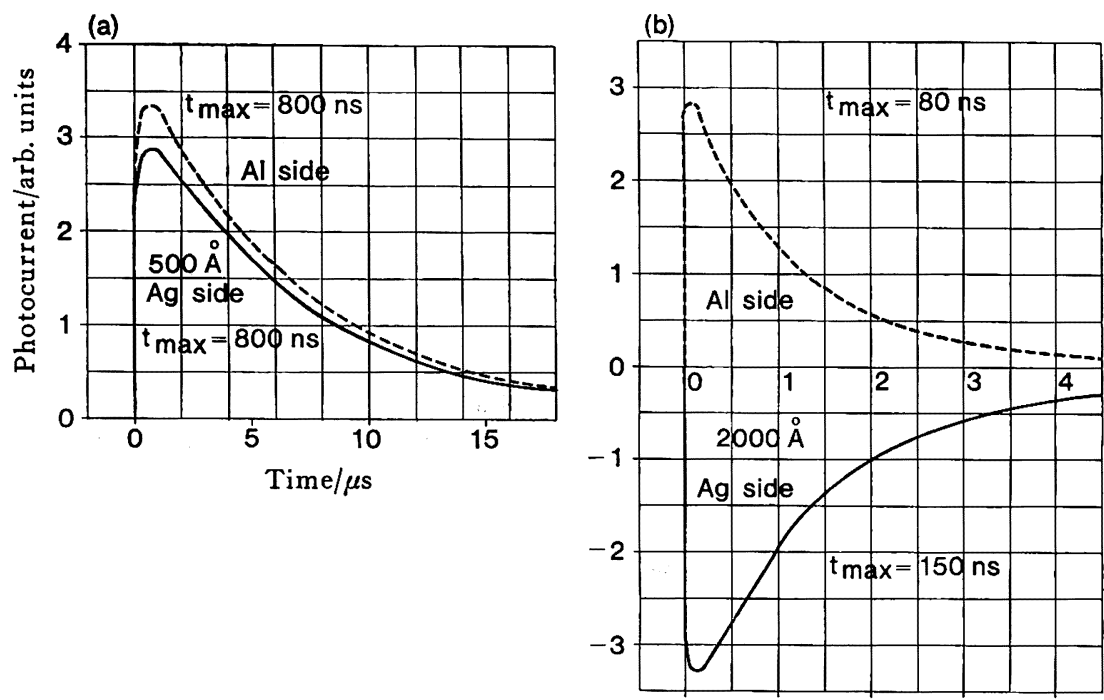

Time $/ \mu \mathrm{s}$

Fig. 8 Transient photocurrent curves obtained by Al side excitation and Ag side excitation

らけた。これらの条件と速度との定量的な関係については現段階 では議論できないが，定性的には蒸着速度が大きいとき（すなわ ち蒸着用ボートの温度が高いとき) 立ち上がり速度は大きくなる 傾向がみられた。実際には（I ）の立ち上がり速度は20ns から 200 nsにわたって変化した。

3.2 .2 過渡光電流の減衰特性 : 過渡光電流は膜厚に依存して 功起後数 $100 \mathrm{~ns}$ から数 $\mu \mathrm{s}$ 後にピークに達し, その後数 $\mu \mathrm{s}$ から 数 $10 \mu \mathrm{s}$ のオーダで減衰する。この減衰曲線は外部抵抗 $R_{e}, R_{\mathrm{a}}$ の值に依存していちじるしく変化する。外部抵抗が $10 \sim 400 \Omega$ の 範囲内では減衰は指数関数 $j(\mathrm{t}) \propto \exp \left(-t / T_{\mathrm{d}}\right)$ でよく近似でき る。減衰時間, $T_{\mathrm{d}}$, はやはりセルの温度には依存しなかった。し かし，立ち上がり時間の場合と異なり， $T_{\mathrm{d}}$ は色素膜厚にいちじる しく依存し，膜厚が大きくなると $T_{\mathrm{d}}$ は小さくなった。さらに立 ち上がり時間は膜の蒸着条件に鋭感に影響をうけたが $T_{\mathrm{d}}$ はまっ たくその影響をらけなかった。隇衰曲線は外部抵抗が $400 \Omega$ 以上 になると指数関数から徐々にはずれてきた。 $R_{\theta}, R_{\mathrm{a}}$ に対して $T_{\mathrm{d}}$ をプロットすると図 7 に示すよらに抵抗が $400 \Omega$ 以下の領域で直 線関係がみられた。
3.2.3 過渡光電流強度の温度, 色素膜厚依存: 前に述べたよ らにセルの温度を室温から液体窒素温度まで下げても過渡光電流 の応答は立ち上がり, 減衰ともに顕著な変化は認められなかった が, 電流のピーク強度は低温にするとともに減少の傾向がみられ た。夜体窒素温度では室温の $50 \%$ 程度まで減少した。さらに特 徽的なことは，このような低温におおてい色素膜に $1 \mathrm{~Hz}$ 程度の くり返しでレーザーパルスを照射すると 1 回の励起ごとに強度が 数十\%ずつ減少した。しばらく低温のまま放置しておくと強度 は回復したが，ふたたび照射をつづけると同様に徐々に減少した。 このよらに光照射をくりかえすことにより強度が減少するのは室 温においてはまったくみられず，低温での測定に特徽的な現象で あった。

つぎに色素膜厚を変化させると，AI 側から光照射した場合は 定常光照射のときと同様に膜厚が $250 \sim 400 \AA$ で光電流強度が最 大になり,さらに膜厚を増すと電流強度は徐々に減少した。しか し，Ag 側から励起した場合は膜厚が $1000 〜 1500 \AA$ までは定常 光照射のときと同様に $\mathrm{Al}$ 側励起よりも光電流は小さく, かつ過 渡応答も $\mathrm{Al}$ 侧励起の場合と一致したが, 膜厚が $1500 \AA$ 以上に 


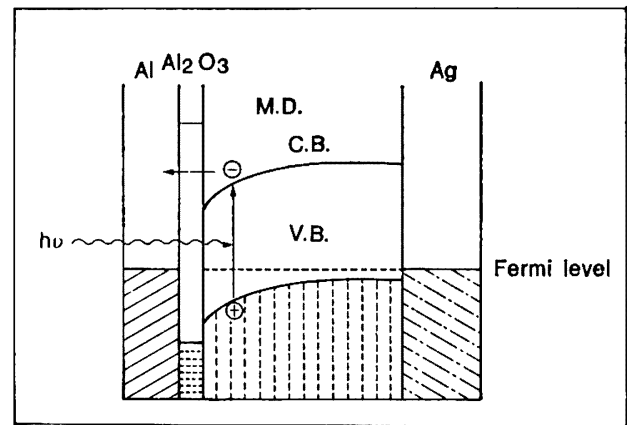

Fig. 9 Energy level scheme of the $\mathrm{Al} / \mathrm{MD} / \mathrm{Ag}$ photodiode

なると Al 側励起の場合と迦向きに電流が流れ，過渡応答曲線も AI 側励起のものと異なった。このようすを図 8 に示す。

\section{4 考察}

\section{1 色素薄膜光ダイオードの等価回路}

数種の金属とメロシアニン薄膜を組み合わせたセルの整流性や 光起電力の特性から，この色素薄膜は $\mathrm{p}$ 型半導体であり $\mathrm{Al}$ と色 素の界面にショットキー型障壁が形成され，Ag と色素はオーミ

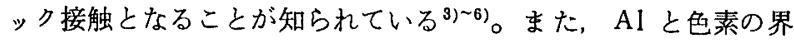
面には A1 の酸化膜が存在しておりいわゆる MIS 構造をもって いると考えられている3。この薄膜光ダイオードのエネルギー構 造の模式図を図 9 に示す。この等価回路を簡単化して, ショット キー障壁によりできるコンデンサー $\left(C_{\mathrm{i}}\right)$ と内部抵抗 $\left(R_{\mathrm{i}}\right)$ を直 列につないだ形のモデルで考える。ただし，色素膜内での電荷の 再結合過程をコンデンサーのリークで表わし，その速度定数を $k$ とする ${ }^{12)}$ 。この等価回路を外部测定回路とともに図 10 に示す。 ここで $C_{\mathrm{i}}$ にたまっている電荷量を $Q(\mathrm{t})$ とする。光励起により 起こる電荷分離過程が励起光パルス愊よりも十分短時間に起き, かつ回路を電流が流れる速度よりも十分に速い場合，初期条件と して,

$$
Q(0)=Q_{0}
$$

と仮定できる。そのとき，オシロスコープ上に钼測される電圧， $E(\mathrm{t})$ ，の時間変化は次式の回路方程式で記述される。

$$
\begin{aligned}
& \frac{Q}{C_{\mathrm{i}}}=R_{\mathrm{l}}\left(j_{1}+j_{2}\right)+j_{1} R_{\mathrm{e}} \\
& R_{\mathrm{e}} J_{1}=\frac{1}{C_{\mathrm{c}}} \int j_{2} \mathrm{~d} t=E(\mathrm{t}) \\
& -\frac{\mathrm{d} Q}{\mathrm{~d} t}=j_{1}+j_{2}+k Q
\end{aligned}
$$

ここで $j_{1}, j_{2}$ はそれどれ $R_{\theta}, C_{\mathrm{\theta}}$ を流れる電流を表わす。この力

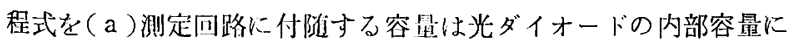
対し十分小さい $\left(1 \gg C_{\mathrm{o}} / C_{\mathrm{i}}\right)$, ( $\left.\mathrm{b}\right)$ 雨絬合に要する時間は回路内 の時定数上りも十分辰い $\left(R_{\mathrm{i}} C_{\mathrm{i}}, R_{\mathrm{e}} C_{\mathrm{e}} \gg 1 / k\right)$ の二つの仮定の下 で解くと ${ }^{19)} E(\mathrm{t})$ は $T_{\mathrm{r}}, T_{\mathrm{d}}$ の時定数でそれぞれ立ち上がり減衰 する形の解をもつ。

19）これらの仮定は後述するように本测定に打いては十分満足 される。

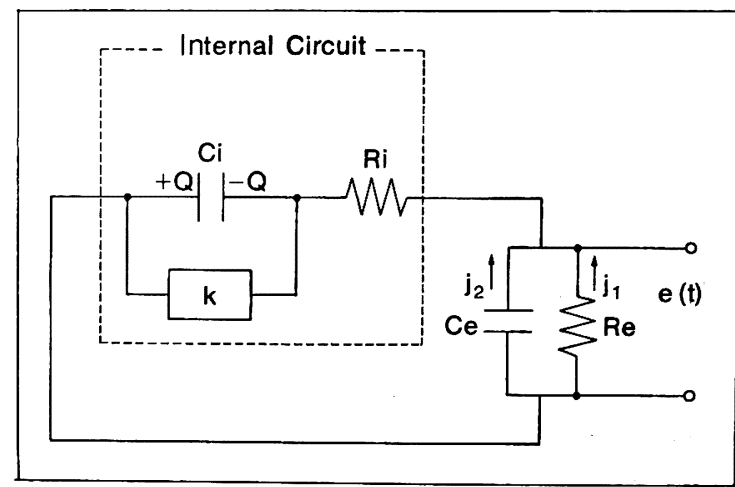

Fig. 10 Simplified circuit with the essential elements used in the analysis

$$
\begin{aligned}
& E(\mathrm{t}) \propto\left\{1-\exp \left(-t / T_{\mathrm{r}}\right)\right\} \cdot \exp \left(-t / T_{\mathrm{d}}\right) \\
& T_{\mathrm{r}} \doteqdot \frac{R_{\mathrm{l}} \cdot R_{\mathrm{e}} \cdot\left(1+\frac{R_{\mathrm{e}}{ }^{2}}{2 R_{\mathrm{I}}} \cdot C_{\mathrm{e}} \cdot k\right)}{\left(R_{\mathrm{1}}+R_{\mathrm{e}}\right) \cdot\left\{1+\left(R_{\mathrm{I}}+R_{\mathrm{e}}\right) \cdot C_{\mathrm{i}} \cdot k\right\}} \\
& \cdot C_{\mathrm{e}}<\frac{R_{\mathrm{I}} \cdot R_{\mathrm{e}}}{R_{\mathrm{i}}+R_{\mathrm{\theta}}} \cdot C_{\mathrm{e}} \\
& T_{\mathrm{d}} \doteqdot \frac{\left(R_{\mathrm{i}}+R_{\mathrm{e}}\right) \cdot C_{\mathrm{1}}}{1+\left(R_{\mathrm{I}}+R_{\mathrm{e}}\right) \cdot C_{\mathrm{I}} \cdot k}
\end{aligned}
$$

$E(\mathrm{t})$ の時間変化は光電流の時間変化に相当するか $\mathrm{b}$ ，“電荷 分離過程が励起光パルス幅にくらべて十分に速い場合” は光電流 は内部抵抗と外部抵抗の並列抵抗を $R_{\mathrm{p}}$, 直列抵抗を $R_{\mathrm{B}}$ として 時定数 $R_{\mathrm{p}} \cdot C_{\mathrm{e}}$ 以内に立ち上がり，ほぼ時定数 $R_{\mathrm{s}} \cdot C_{1}$ で減衰する ことがわかる。

\section{2 過渡光電流応答を支配する因子}

実際に本研究で得られた過渡光電流の立ち上がりは励起パルス 幅よりも十分僬く, かつセルの内部抵抗, 外部抵抗の值に依存し なかった。本測定回路の立ち上がり応答時間は， $C_{\theta}$ はせいぜい $100 \mathrm{pF}$ の程度なので $R_{\theta}$ として $10 \Omega$ を用いたとき(6)式から

$$
T_{\mathrm{r}}<R_{\mathrm{p}} \cdot C_{\mathrm{e}}<R_{\mathrm{e}} \cdot C_{\mathrm{e}} \doteqdot 1 \mathrm{~ns}
$$

と励起光パルス幅よりも十分速い。また，電荷キャリヤーが色素 膜内を一方の面から他方の面まで走るのに要する時間（transit time, $T_{\mathrm{t}}$ ) は次式から得られる ${ }^{20)}$ 。

$$
T_{\mathrm{t}}=\frac{l^{2}}{\mu V}
$$

ここで $l$ は色素膜厚, $\mu$ は電荷キャリヤーの移動度, $V$ は膜の両 端にかかる電圧である。本研究の場合 $l=200 \AA$ のときに $V=$ $V_{\text {oc }} \doteqdot 1 \mathrm{~V}, \mu=10^{-1} \sim 10^{-2} \mathrm{~cm}^{2} \cdot \mathrm{V}^{-1} \cdot \mathrm{s}^{-17) 21)}$ の值を用いると $T_{\mathrm{t}}=$ $0.4 \sim 0.04 \mathrm{~ns}$ となり励起光パルスよりも短いことがわかる。

以上の考察から，電荷キャリヤーの生成が励起パルス幅よりも 短い特間内に起これば，光電流は励起光パルスに追随して上昇す ることになる。しかし，電荷キャリヤー生成速度がこれからの速 度よりも遅いときにはその過程が律速になり，電流の立ち上がり

20）たと学ば，“新実験化学講座，基礎技術 4, 電気”，丸善 (1976) p. 187

21) H. Killesreiter, R. Braun, Phys. Stat. Sol.(b), 48 , 201(1971). 
は励起光パルス幅よりも遅れることになる。よって本研究で得ら れた立ち上がり速度は電荷キャリヤー生成の速度を反映した量と 結論できる。

つぎに過渡光電流の減衰であるが, Ghosh らはフタロシアニ ン膜の場合には電荷キャリヤーが膜中でトラップされる過程によ り減衰が規定されていると考えている7。しかし本研究の場合 (i)外部抵抗が小さいとき指数関数的減衰を示すこと, (ii)その 時定数は外部抵抗の值と直線関係にあることなどの理由により等 価回路の考察で得られた（5)式にしたがい，（7)式で与えられる 回路の時定数 $T_{\mathrm{d}}$ で過渡光電流は減衰すると考えられる。文のと き, 減衰の時定数と外部抵抗の間に直線関係が認められる抵抗の 範囲内 $\left(R_{\mathrm{e}}, R_{\mathrm{a}}<400 \Omega\right)$ では $R_{\mathrm{s}} \cdot C_{1} \cdot k$ が 1 より十分小さく無視 できて(7)式は

$$
T_{\mathrm{d}} \doteqdot R_{\mathrm{s}} \cdot C_{\mathrm{I}}
$$

ただし，

$$
R_{\mathrm{B}}=R_{\mathrm{1}}+R_{\mathrm{\theta}}+R_{\mathrm{a}}
$$

と表わせると考えると実験結果をらまく説明できる。その場合図 7 から光ダイオードの内部抵抗， $R_{\mathbf{i}}$, が求められる ${ }^{12)}$ 。色素膜厚

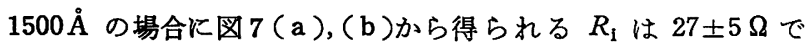
誤差範囲内で一致する。一方, 同じセルで $\mathrm{Al}$ 膜と $\mathrm{Ag}$ 膜間の抵 抗を実際に测定すると, 暗所で約 $3 \mathrm{~m} \Omega, 1 \mathrm{~mW}$ の単色光 (540 $\mathrm{nm})$ 照射下で約 $700 \mathrm{k} \Omega$ であった。これらの結果は一見矛盾す るよらである。しかし，この大きな抵抗はほとんど色素膜内に存 在する空間電荷層の抵抗であると考えられる。等価回路モデルに おいては， $C_{1}$ に $R_{1}$ が直列につながっており，空間電荷層の抵 抗は電荷キャリャーの再結合がないとき仮定しており， $R_{\mathrm{i}}$ はバンドがフラットな領域の色素膜の抵抗と金属膜の抵抗の直列 抵抗に相当している。すなわちパルス光の実験からはこの直列抵 抗が内部抵抗として得られたことになる。

さらに図 7 の傾きから内部容量, $C_{1}$ が求められる。このよう にして色素獏厚の異なるいくつかのセルについて求めた $R_{1}, C_{1}$ の値を表 2 に示す。同時に，セルの容量をインピーダンスアナラ イザーを用いて周波数 $100 \mathrm{kHz}$ で測定した結果も記す22)。减衰 曲線から求めた容量と実測の容量とが比較的よくあっていること からこの解析方法は重要であると考兄られる。また， $C_{\mathrm{i}}$ は 100 $\mathrm{nF}$ のオーダであり， $C_{0}(<100 \mathrm{pF})$ よりも十分に大きく，前に用 いた仮定が正しかったことがわかる。

以上のよらに光電流の過渡応答曲線を支配する因子が明らかに なり,それからいくつかのパラメーターが妥当な值として得られ た。しかし，前に述べた過渡光電流強度の低温での 異常な挙動 や，色素膜厚が大きいときの逆向きの光電流の出現などは現段階 では説明がつかず, 今後の問題として残されている。

\section{3 光電流発生機構}

過渡光電流の立ち上がり速度は電荷キャリヤー生成過程が反映 されていることが前の考察から明らかになった。そこでメロシフ

22）色素薄膜サンドイッチセルの容量は一般的に周波数分散を 示すが,ここでは減衰の時定数が $1 \sim 20 \mu \mathrm{s}$ ( $50 \mathrm{kHz} \sim 1$ $\mathrm{mHz})$ の範囲内で因 7 の傾きから容量を求めているので インビーダンスフナライザーを用いた測定もその範团内の 周波数を用いた。そのとき周波数分散は小さいので, 代表 的な値として $100 \mathrm{kHz}$ での值を示した。
Table 2 Values of the internal capacitance and internal resistance obtained from the decay time of the transient photocurrent

\begin{tabular}{cccc}
$\begin{array}{c}\text { Dye film } \\
\text { thickness }\end{array}$ & $C_{1}{\text { (calc. })^{a)}}^{(} C_{\mathrm{i}}$ (measure) $)^{b)}$ & $R_{1}$ \\
\hline $370 \AA$ & $175 \mathrm{nF}$ & $160 \mathrm{nF}$ & $30 \pm 5 \Omega$ \\
$670 \AA$ & $110 \mathrm{nF}$ & $90 \mathrm{nF}$ & $47 \pm 5 \Omega$ \\
$1050 \AA$ & $78 \mathrm{nF}$ & $60 \mathrm{nF}$ & $23 \pm 5 \Omega$ \\
$1500 \AA^{c)}$ & $57 \mathrm{nF}$ & $31 \mathrm{nF}$ & $27 \pm 5 \Omega$
\end{tabular}

a) Calculated values from the decay curves of the transient photocurrent.

b) Measured by an impedance analyzer at $100 \mathrm{kHz}$.

c) The conditions of dye evaporation are different from other three cells.

ニン蒸着薄膜の場合の電荷キャリヤー生成過程について考察す る。

有機色素膜，または有機半導体に怙ける電荷キャリヤーは励起 子を介して生成すると考劣られている ${ }^{23)}$ 。この解離過程にはつぎ の3機構が考えられている28)。

（1）高い励起状態での自動解離, または励起子一励起子の衝 突による解離。

（2）電極，または半導体界面での励起子の解離。

（3）バルク中で励起子と不純物, またはトラップとの相互作 用による解離。

（1）の場合は励起波長，入射パルス光強度にいちじるしく依存 するはずである。しかし，本研究で励起波長を 450 ～600 nm に わたって変化させてもまったく立ち上がり速度に影響はなかっ た。また, 励起光強度依存性からも電流は光強度に対して一次に 增加し，さらに立ち上がり，減衰とも光強度に影響をうけないな ぞの事実から，本系においては(1)の生成機構は除外することが できる。そこで(2)，または( 3 )のバルク中，または界面での励 起子の解離過程が重要になってくる。すなわち, 励起子の拡散過 程が立ち上がりを決めていると考兄られる。

Killesreiter らは21) $p$-クロラニルとアントラセンの単結晶を 電解質の水溶液中に入れて, パルス光照射により光電導度を測定 している。また, 電荷分離が結晶と水の界面のみで起こる場合に 外部回路を流れる電流の時間変化を表わす式を励起子の拡散方程 式を解くことにより得て，実験結果をよく説明している。彼らの 結果によると, 単結晶がほぼ均一に励起されて, かつ界面での電 荷分離の速度が十分速いときには, 外部回路を流れる電流, $j(\mathrm{t})$, は時刻 $t$ が小さい領域では励起子の拡散過程により決まり, 次式 で表わすことができる。

$$
j(\mathrm{t})=A \cdot \sqrt{t}
$$

ここで $A$ は比例定数で拡散係数と膜厚に依存する。

本研究で得られた立ち上がり時間一電流強度を対数一対数プロッ トした結果を図 11 に示す。ある時間領域では，Killesreiter ら の場合と類似して $\sqrt{t}$ にしたかって電流強度が増加していること がわかり，励起子の払散過程が立ち上がりを決めていると推定で きる。ただし，(12)式での傾き，Aはこの場合は膜厚によらず

23）たとえば, F. Gutmann, L. E. Lyons, "Organic Semiconductors", John Wiley \& Sons, Inc., New York (1967). 


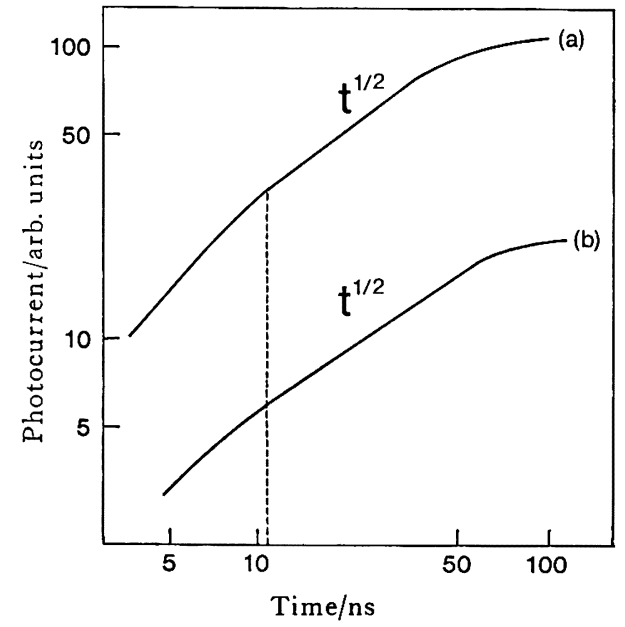

Fig. 11 Log-log plot of the initial photocurrent, revealing the square-root dependence of the current on time after the duration of excitation pulse, $j(\mathrm{t}) \propto \sqrt{t}$

Dye film thickness $(\AA):(a) ; 1500$, (b ) ; 370

に，膜の作成条件に依存する。これは電荷分離が色素膜と金属の 界面のみで起きているのではなく，膜中でも起きていると考学る と説明可能である。本研究で用いたのは蒸着膜であるから単結晶 の場合とは異なり，膜中に不純物、トラップなどが数多く存在し ており，バルク中での電渮分離過程が起きるためと推定できる。

以上の結果から光電流に荷与する励起子脃色膜内を数 10〜 数 $100 \mathrm{~ns}$ の間払散していると結論される。一方, 発光寿命の測 定から一重項励起子の寿命は $200 \mathrm{ps}$ と決定されている。そこで メロシアニン蒸着膜の場合は電荷キャリヤーは一重項励起子とは 異なり，寿命が少なくとも数 $100 \mathrm{~ns}$ 以上ある中間体を介して生
成すると考えられる。この長寿命中間体としては三重項励起子が 考えられるが，それを確認するためにはリン光測定などの実験が 今後必要となろう。

また，生成した電荷キャリヤーの膜内での再結合の速度定数は 等洒回路モデルの中で $k$ で表わされており，この值は外部抵抗を 適当に大きな値 $(400 \Omega$ 以上) にすることにより（7)式から見積 もることができる。 $R_{0}$ として $985 \Omega$ を用いてこの值を求めると $1 / k=2 \times 10^{-4} \mathrm{~s}$ であった。これは回路中の時定数よりも十分大き く(5)〜（7)式を求めるさいに用いた仮定が正リかったことがわ かる。

\section{5 結 論}

発光寿命の測定からメロシアニン色素蒸着薄膜の一重項励起子 の寿命は約 200 ps であることがわかった。また，過渡光電流の 応答曲線において立ち上がりは，励起子の拡散過程により決ま り，電荷キャリヤーは三重項励起子のような寿命が少なくとも数 $100 \mathrm{~ns}$ 以上ある中間体を介して生成することが推定された。電 荷分離は金属と色素の界面のみならず，色素膜バルク中でも起き ていると考只られる。過渡光電流の減衰は回路の時定数で決ま り, その值から色素膜内での電荷キャリヤーの再結合過程の速度 定数は約 $5 \times 10^{3} \mathrm{~s}^{-1}$ と得られた。

以上のように，励起光源としてパルスレーザーを用いた過渡光 電流の測定は定常光実験では得られなかった多くの情報を与えて くれることを明らかにした。

終りに, 発光寿命の測定のさいには分子科学研究所山崎 厳助 教授とKlaus Kemnitz 博士の援助を頂きました。回路の応答速 度の議論については東京大学伊藤公紀博士から有意義な助言を頂 きました。また, 本研究の初期には, 大阪大学川合知二助教授か ら適切な助言を頂きました。ここに心からお礼申し上げます。本 研究は 1982〜83 年にわたって分子科学研究所の協力研究のプロ グラムで援助されたことを付記します。

\title{
Special Articles on Functional Surface and Interface
}

\author{
Transient Photocurrent and Luminescence Lifetime in the \\ Photodiode of Merocyanine Dye Thin Film \\ Kazuhito Hashimoto, Tadayoshi Sakata*, Yukihiro Ozaki**, \\ Masahiko Yoshiura** and Keiji IrIyama** \\ Institute for Molecular Science ; Nishigonaka, Myodaiji, \\ Okazaki-shi 444 Japan \\ ** Division of Biochemistry, Central Research Laboratory, \\ The Jikei University School of Medicine ; Nishi-shinbashi, \\ Minato-ku, Tokyo 105 Japan
}

The mechanism of photocurrent generation in organic dye photodiode was studied by measuring both transient photocurrents with a nanosecond laser, and luminescence lifetimes with a picosecond laser and a time-correlated photon counting system. The photodiode consists of an evaporated merocyanine dye film sandwiched between two different metals such as $\mathrm{Al}$ and Ag. The lifetime of a singlet exciton in the evaporated merocyanine film determined from 
the fluorescence lifetime is about 200 ps. A simple analytical model of transient photocurrent was proposed. The model treats the system as a $\mathrm{RC}$ circuit with a rate constant for a recombination of charge carrier in the dye film. The intensity of the transient photocurrent gradually increases for several hundred nanoseconds after the excitation. From the analysis of the rise curves, it is concluded that the rise time is determined by the diffusion process of an exciton in the bulk of the dye film. These results infer that the charge carrier is generated from an intermediate species with a lifetime of more than several hundred nanoseconds.

Moreover, it is considered that the charge separation occurs not only at the interface of the dye film and the metal but also in the bulk of the dye film. The decay time of the transient photocurrent was found to be determined by the RC constant of the circuit. The values of internal capacitances and internal resistances of the photodidodes were obtained. The rate constant of the recombination of charge carriers was also estimated to be about $5 \times 10^{-3} \mathrm{~s}^{-1}$. Moreover, some interesting phenomena peculiar to pulse light excitation were observed. 